\title{
A Chinese Porcelain Jar Associated with Marco Polo: A Discussion from an Archaeological Perspective
}

\author{
Lin Meicun ${ }^{1}$ and Ran Zhang ${ }^{2}$ \\ ${ }^{1}$ School of Archaeology and Museology, Peking University, China \\ ${ }^{2}$ Department of Archaeology, Durbam University, $U K$
}

As the first European to claim that he travelled to China and back, Marco Polo is a celebrated traveller who described the multicultural society of Eurasia in the thirteenth to fourteenth centuries AD. However, his famed account, the Travels of Marco Polo, contains many unsolved mysteries which have generated discussion among historians, while an archaeological approach has been even less convincing because the material that may link to Marco Polo is very rare. A recent re-analysis of Chinese ceramics from a wide geographical area ranging from southern China to the Indian Ocean provides some archaeological support: it suggests that a Chinese porcelain jar housed in the Treasury of San Marco in Venice dates to the era of Marco Polo and is associated with his journey to China.

Keywords: Marco Polo, Qingbai porcelain jar, Chinese ceramics, Indian Ocean trade

\section{INTRODUCTION}

The Travels of Marco Polo is an important but questionable historical document (see, for example, Moule \& Pelliot, 1938: 41; Jackson, 1998: 84-86). This account of lengthy travels along Eurasian land and sea routes around the thirteenth to fourteenth centuries $\mathrm{AD}$ constitutes a key document for historians to decipher about the perception of the multicultural society that Polo encountered on his way to China. But the authenticity of Polo's travels, in particular his 'visit to China', is still an issue that contemporary historians debate: for instance, many scholars (Yule \& Cordier, 1903; Penzer, 1929; Olschki, 1960; Franke, 1966; Haeger, 1978; Wood, 1996) argue that Marco Polo did not actually visit many of the localities which he claims to have seen on his journey, including Burma, the
Arabian Sea, the Indian subcontinent, Java, and some cities in China; and that Marco Polo reported hearsay about China acquired in Italian merchant colonies positioned around the Black Sea. But supporters of Marco Polo argue (De Rachewiltz, 1997; Haw, 2006) that his return journey from China has been historically recorded in Chinese history and Arab accounts (Yang \& Ho, 1945; Pelliot, 1959-73), and that his detailed descriptions of paper money and salt production provide supporting evidence of his visit to China (Vogel, 2012). The mid-point in this debate argues that Marco Polo did in fact visit China, but that he exaggerated and falsified details about his visit and sojourn: for example, it is possible that Marco Polo did serve in the Imperial Salt Monopoly in Yangzhou, but not as a governor (Morgan, 1996: 233). 
This historical debate has not been considered by archaeological studies for many decades. Given that it is such a short-lived historical event, no (or rare) archaeological evidence can be found to link to the travels of Marco Polo. The only discussion on the material culture associated with Marco Polo was undertaken by Oscar Raphael (1932), when he visited the Basilica of San Marco in Venice. He suggested that a Chinese Qingbai porcelain jar housed in its Treasury was probably brought back by Marco Polo from China (Raphael, 1932; Dubosc, 1954: 156, cat. no. 565) (see below for a detailed description). Although this has been widely accepted by many archaeologists (Whitehouse, 1972: 71-72; Morgan, 1991: 71; Horton et al., 1996: 310; Flecker, 2003: 397-98; Kennet, 2004: 63), no further research has examined the manufacturing and dating evidence for this so-called 'Marco Polo jar' and similar ceramic finds (so-called 'Marco Polo wares') from archaeological sites of the Indian Ocean. It is therefore understandable that, because of the lack of material evidence and discussion, archaeologists have been reticent to engage in the debate over Marco Polo's visit to China.

This article examines the distribution of 'Marco Polo wares' across a wide geographical area. It suggests a hypothetical date of the 'Marco Polo jar' on archaeological grounds and revisits the production of Chinese 'Marco Polo wares' and their consumption across the Indian Ocean. In addition, Marco Polo' visit to China is reevaluated.

\section{The Current View: Why is the Dehua Qingbai Porcelain Jar Associated with Marco Polo?}

In terms of material cultural evidence, a Chinese Qingbai porcelain jar, known as the 'Marco Polo jar', housed in the
Treasury of San Marco in Venice, may be the only artefact linked to Marco Polo and his visit to China. This jar is about $12 \mathrm{~cm}$ tall, with a maximum diameter of $8.1 \mathrm{~cm}$, a low foot-ring, and a short neck with four small loop-shaped lugs. It has a hard, white, thin body that is coated with Qingbai (青白 literally: bluish white) cream glaze. There are four zones of decoration presented in relief on the surface of the jar, consisting of two bands of floral scrolls in the middle and two bands of petal-like motifs near the top and bottom of the jar (Figure 1).

Originally it was suggested that this Qingbai porcelain jar had been brought back by Enrico Dandolo (Doge of Venice) from St Sophia after the fall of Constantinople during the Fourth Crusade of AD 1204 (Raphael, 1932: 14), but initially Oscar Raphael had argued that this dating was too early, following an examination of the shape of Yuan Chinese ceramics (AD 1276 to 1368) (Raphael, 1932: 14). The San Marco jar was associated with Marco Polo because its dating matches the era of the travels of Marco Polo, and therefore might be the only surviving piece of Marco Polo's treasures reputed to have been brought back from China to Venice in $\mathrm{AD}$ 1295 (Raphael, 1932: 14). Raphael further suggests that this jar may have been produced in the Dehua kilns in Fujian province in southern China (Raphael, 1932: 13-14). And his argument may be supported by similarly shaped Qingbai stonewares found in vast numbers in many local kilns in Fujian province (Dehua Guciyao Kaogu Fajue Gongzuodui, 1979; Ke \& Chen, 1995; Ye, 2005).

As for the wider archaeological context, many Dehua Qingbai porcelain fragments of a type similar to the 'Marco Polo jar' have been found on archaeological sites and shipwrecks in the Indian Ocean (see below for detailed discussion). It has been suggested that these ceramic finds be called 'Marco 


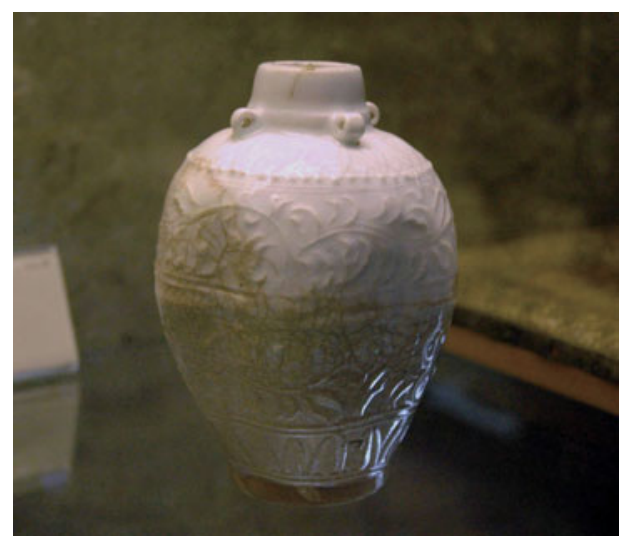

Figure 1. The 'Marco Polo jar' housed in the Treasury of the Basilica of San Marco in Venice (photograph by Lin Meicun).

Polo wares' (Ayers, 1988: 16-17) and this term has been adopted by archaeologists. However, because these findings seem to be ambiguously defined, poorly dated, and vaguely described, confusion has arisen when archaeologists have attempted to understand their chronology. Some basic attempts have been separately made by Whitehouse (1972: 71-72), Morgan (1991: 71), Horton et al. (1996: 310), Flecker (2003: 397-98), and Kennet (2004: 63), who believe that many of these wares were made in the Dehua kilns, Putian kilns, or Anxi kilns in the Fujian province of southern China, following the examples published by Hughes-Stanton and Kerr (1980: no. 186). However, no further evidence has been discussed on the parallel production of 'Marco Polo jars/wares' within the Chinese ceramic industry.

\section{Historical and Archaeological Evidence for the 'Marco Polo Jar'}

Initial historical discussions of Marco Polo's travels in China have emphasized the Dehua ceramic industries witnessed by Polo (Feng, 2001: 375-80; Xiong, 2006: 28), but no study establishes the link between these historical accounts and the archaeological evidence. A general review, from the production of Qingbai porcelain wares in China to their consumption in the Indian Ocean during the era of Marco Polo, serves here to provide a wider geographical overview of the current historical and archaeological evidence.

\section{Description of the ceramic industry in Southern China by Marco Polo}

In modern English, the word 'porcelain' is thought to have been coined by Marco Polo from 'porcellino', which in Italian refers to the piglet-like shape of a cowrie shell, hence a translucent shell. For the first time, Marco Polo linked Chinese ceramics to a thin, white shell to describe porcelain (Hamer \& Hamer, 1975: 229). Marco Polo claims to have had a chance to view the Dehua kilns in Fujian province, the original manufacturing place of the 'Marco Polo jar'.

In the Travels of Marco Polo, there are two places that are linked to Chinese ceramic manufacture: 'Zayton (Zai-tun, Zarten, Zai-zen, Caiton or Tsuen-Cheu)' and 'Tingui (Tiunguy, Tin-gui or Tingiu)' (see Wright, 1854: 343-46; Feng, 2001: 375-80; Cliff, 2015: 221-24). Marco Polo wrote:

The river that flows by the port of Zaitun is large and rapid... At the place where it separates from the principal channel stands the city of Tin-gui. Of this place there is nothing further to be observed, than that cups or bowls and dishes of porcelain-ware are there manufactured.' (Wright, 1854: 345)

The identification of the port of Zayton is now agreed to be Quanzhou port (泉州 港), which was one of largest sea ports in southern China at that time. The name 'Zayton' comes from the Arabic name for 
Quanzhou, and represents the trees called Citong (刺桐, Erythrina variegate, or the Tiger Claw Tree), which were planted around the city walls (Feng, 2001: 378-79; Cliff, 2015: 387, note 64). On the other hand, the interpretation of Tingui varies. For example, it has been thought to be 'Tingzhou (汀州)', present-day Changting (长汀), which is located near the western border of Fujian province (Wright, 1854: 345; Cliff, 2015: 387, note 66), but Feng Chengjun has a different opinion and suggests that it is Dehua City (德化) near Quanzhou. He argues that Tingui might represent the name for Quanzhou, and, geographically, that Dehua is part of Quanzhou. Marco Polo was using Zayton to describe Quanzhou port and Tingui is therefore used to describe Dehua (Feng, 2001: 378-80).

There is parallel evidence to match Marco Polo's description concerning the southern Chinese ceramic industry, and the archaeological material seems to indicate that Dehua is correct. Indeed, from Marco Polo's description, there is nothing but the ceramics industry in Tingui City. Marco Polo further notes that: Great quantities of the manufacture [of porcelain] are sold in the city, and for a Venetian groat you may purchase eight porcelain cups' (Wright, 1854: 345; Cliff, 2015: 387, note 66). The archaeological discoveries in Changting County showed that there was a small-scale ceramics industry, which mostly dates to the Song dynasty (AD 960-1274) (Deng, 1993), i.e. earlier than Marco Polo's time. By contrast, Dehua City had a well-established ceramics industry in Marco Polo's time (Dehua Guciyao Kaogu Fajue Gongzuodui, 1979; Fujiansheng Bowuguan, 1990). In addition, as already mentioned, the socalled 'Marco Polo jar' in the Treasury of San Marco is thought to have been produced by a Dehua kiln. It seems therefore reasonable to accept that Dehua City is the Tingui City mentioned by Marco Polo.

\section{The Qingbai ceramic industry in Fujian province, china}

In order to better understand the 'Marco Polo jar' and 'Marco Polo wares', a comprehensive overview of the Chinese Qingbai ceramic industry is necessary (Figure 2). It is believed that Qingbai ware was first manufactured in the tenth century in the Jingdezhen kilns in Jiangxi province of southern China, and gradually became popular over the following three centuries (see Jiangxisheng Wenwu Kaogu Yanjiusuo \& Jingdezhen Minyao Bowuguan, 2007). With the concurrent development of maritime trade, Qingbai stoneware became a popular ceramic commodity on cargo lists. In addition to the Jingdezhenproduced Qingbai wares, the bluish-white/ greyish-white wares produced in the local kilns of Fujian and Guangdong were also widely exported. Consequently, during the twelfth to thirteenth centuries there was an economic and industrial boom in the Fujian local ceramic kilns (see Ho, 2001). During the time of this large-scale production of Qingbai ceramics in southern China, the Dehua kilns in Fujian province became important for producing moulded Qingbai ceramics in the thirteenth to fourteenth centuries (see Dehua Guciyao Kaogu Fajue Gongzuodui, 1979; Fujiansheng Bowuguan, 1990; Lin \& Zhang, 1992: 564).

The history of Qingbai stonewares at the Dehua kilns can be traced back to the early twelfth century and production continued up to the sixteenth century (Dehua Guciyao Kaogu Fajue Gongzuodui, 1979: 57; Chen, 1999; Fujiansheng Bowuyuan, Dehuaxian Wenwu Guanli Weiyuanhui \& Dehua Taoci Bowuguan, 2006). There are two major kiln sites that have been excavated: the Wanpinglun kiln site (碗坪仑 窑址) (see Fujiansheng Bowuyuan, 1990) and the Qudougong kiln site (屈斗宫窑 址) (see Dehua Guciyao Kaogu Fajue 

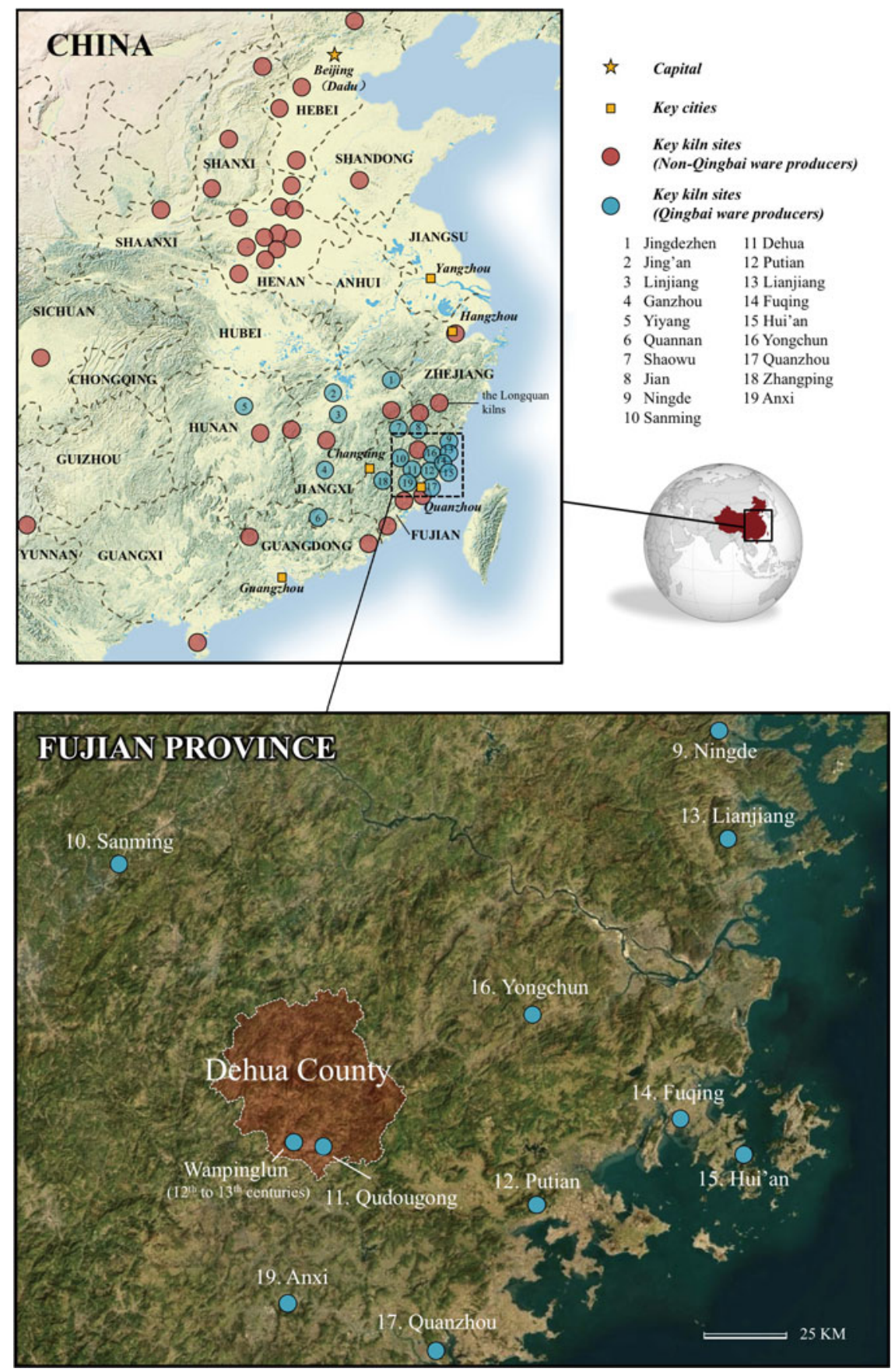

Figure 2. A sketch map of the Chinese ceramic industry and locations of Qingbai ceramic producers in Fujian province during the fourteenth century (drawing by Ran Zhang). 
Gongzuodui, 1979; Fujiansheng Bowuguan, 1990), which can be independently dated to the twelfth to thirteenth centuries (Chinese southern Song dynasty) and late thirteenth to fourteenth centuries (Yuan dynasty: AD 1274-1368) (see Lin \& Zhang, 1992). The moulded reliefs on the Qudougong Qingbai stoneware products can be distinguished from the wares found at the Wanpinglun kiln site (Lin \& Zhang, 1992: 564), and are very similar to the jar housed by the Treasury at San Marco in Venice (Figure 3).

When considering the dating of the Dehua sites, it has been argued that the Qudougong kiln site is later than the kiln at Wanpinglun, and that the Qudougong site dates to the late thirteenth century and mostly the fourteenth century AD (see Lin \& Zhang, 1992). The dating evidence for the Qudougong site is mainly based on some ceramic figures with Mongolian garments, which could suggest that the northern Chinese culture was imported to southern China during the Yuan dynasty (Dehua Guciyao Kaogu Fajue Gongzuodui, 1979: 57), and also on some pieces of kiln furniture excavated at the Qudougong kiln sites which have inscriptions in Phags-pa script (Dehua Guciyao Kaogu Fajue Gongzuodui, 1979: 57). This was a new alphabet introduced by Kublai Khan in $\mathrm{AD} 1269$, and its implementation in southern China would therefore date to after $\mathrm{AD}$ 1274, when the Mongolian rulers conquered the whole of China. Kiln furniture fragments with Phags-pa script have also been found at the Laohudong kiln site in Hangzhou City (e.g. Wang, 2004: 89, fig. 45) and the Longquan kiln sites in Zhejiang province (Zhu, 1989: 28), which can be dated to the Yuan dynasty. Finally, some clay boxes with a cyclical date of 'dingwei (丁未)' were unearthed at the Qudougong site, which suggest two possible years during the Yuan Mongols' reign, i.e. $\mathrm{AD} 1307$ and 1367 (see further discussion below) (Fujiansheng Bowuguan, 1990: 140-42; Lin \& Zhang, 1992: 565).

Finally, rather than just being produced at the Dehua kilns, it seems that 'Marco Polo wares' were widely produced in the southern Fujian province at kiln sites such as Yongchun (永春窑) (Zeng, 2001: 173), Putian (莆田窑) (Li, 1979; Ke \& Chen, 1995: 612), Anxi (安溪窑), and Quanzhou (泉州窑) (Li, 1960; Anxixian Wenhuaguan, 1977; Zhang, 1989; Lin, 1999). The wares from these sites all seem to share the same style and firing techniques as Qingbai wares and are dated to the Yuan dynasty (Figure 4).

\section{An overview of the 'Marco Polo jar' finds in the Indian Ocean}

'Marco Polo wares' normally have a Qingbai glaze, which is thin, glassy, and not very hard. The well-fired fabric is bluish-white, but pure white, yellowish-white, and greyish-white are also found, and some wares have crazing (Dehua Guciyao Kaogu Fajue Gongzuodui, 1979: 55). In terms of shapes, the most common are bowls, bowls with a pointed body, plates, covered boxes, kendi (pouring vessels with a spout, see Figure 3.13), and jars. They are normally not very large, with the mouth diameter of the bowls and plates usually no larger than $23 \mathrm{~cm}$. Unglazed rims and flat-bases are common, and some tablewares are half glazed on the outside. According to the archaeological findings from the Qudougong site, Qingbai ceramic forming, setting, and firing techniques were not standardized, resulting in variations in shape (Dehua Guciyao Kaogu Fajue Gongzuodui, 1979: 55-56). As for decorations, moulded patterns are very common and mainly consist of lines, a band of classic scroll, flowers (including decorative lotus petals, lotus, chrysanthemums, peonies, and plum blossom), clouds, and phoenixes, while on 


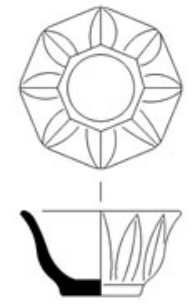

1
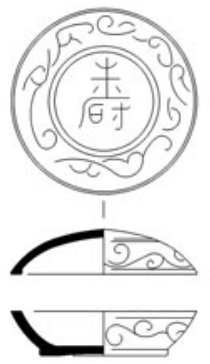

2
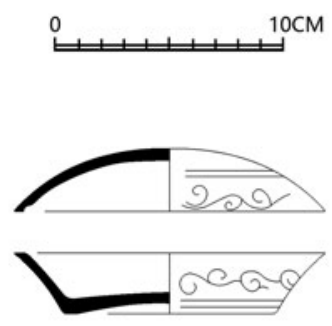

3

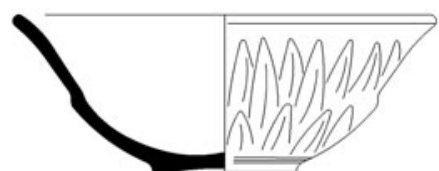

4

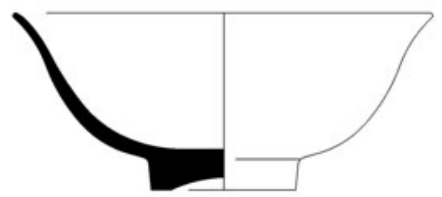

5

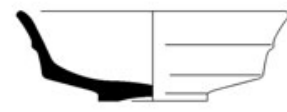

6

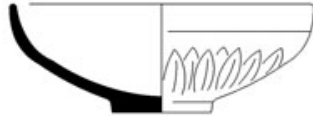

7

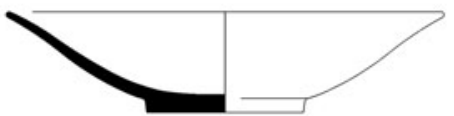

8

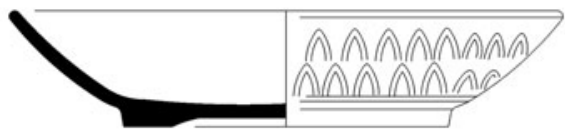

9
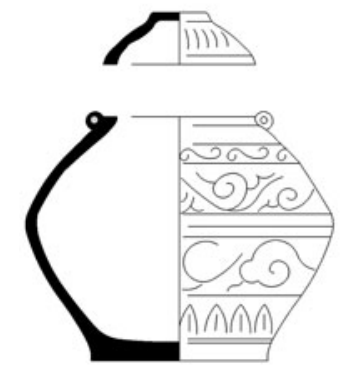

11

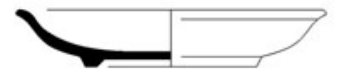

10

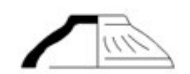

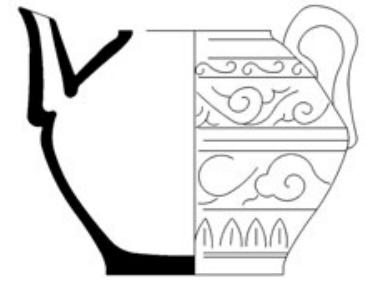

12

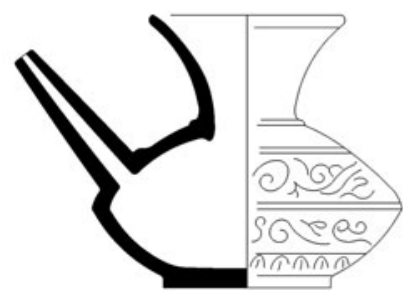

13

Figure 3. Drawings of Qingbai stonewares from the Qudougong site. 1) cup; 2-3) bowls with lids; 4-8) bowls; 9-10) plates; 11) jar with lid; 12) pot; 13) kendi (re-drawn by Ran Zhang, after Dehua Guciyao Kaogu Fajue Gongzuodui, 1979).

plain wares carved decorations and applied patterns can also be found (Dehua Guciyao Kaogu Fajue Gongzuodui, 1979: 57-58) (Figures 5 \& 6).
The distribution of Marco Polo type/ Dehua Qingbai wares across the Indian Ocean is mainly in the Malacca area, southern India, the Persian Gulf, and 


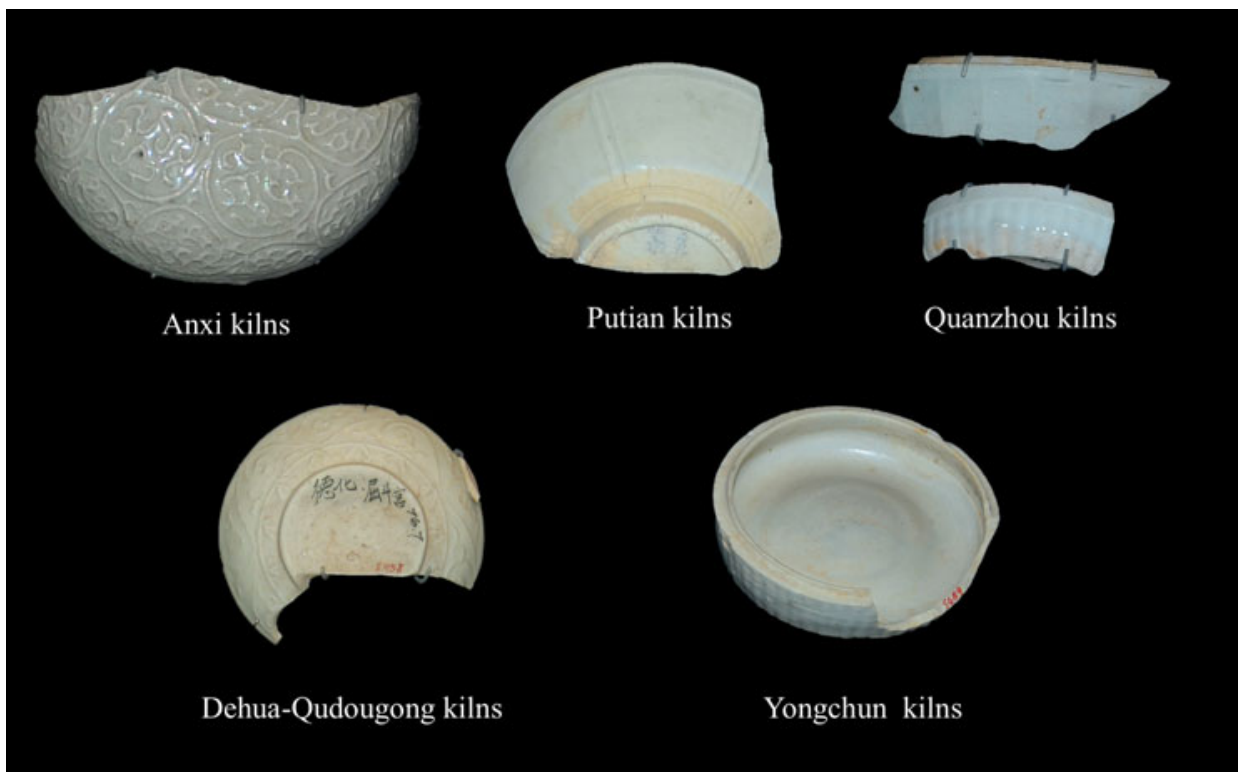

Figure 4. Qingbai ceramic wares from Fujian local kilns, from the collections in the Palace Museum, Beijing. () Wu Ning. Reproduced by permission of Wu Ning.

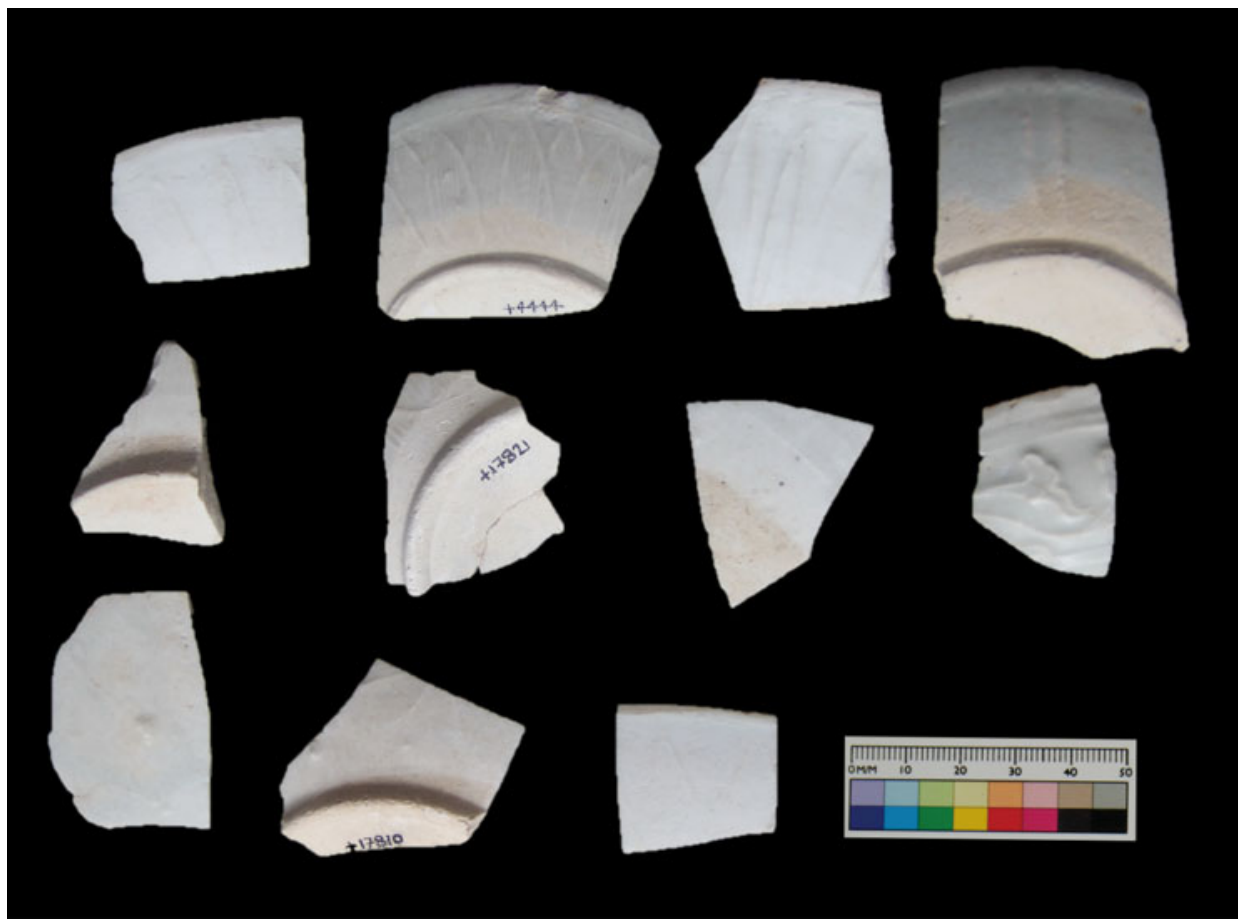

Figure 5. Dehua Qingbai stoneware sherds discovered in the Minab area, southern Iran, from the Williamson Collection (photograph by Lin Meicun). 


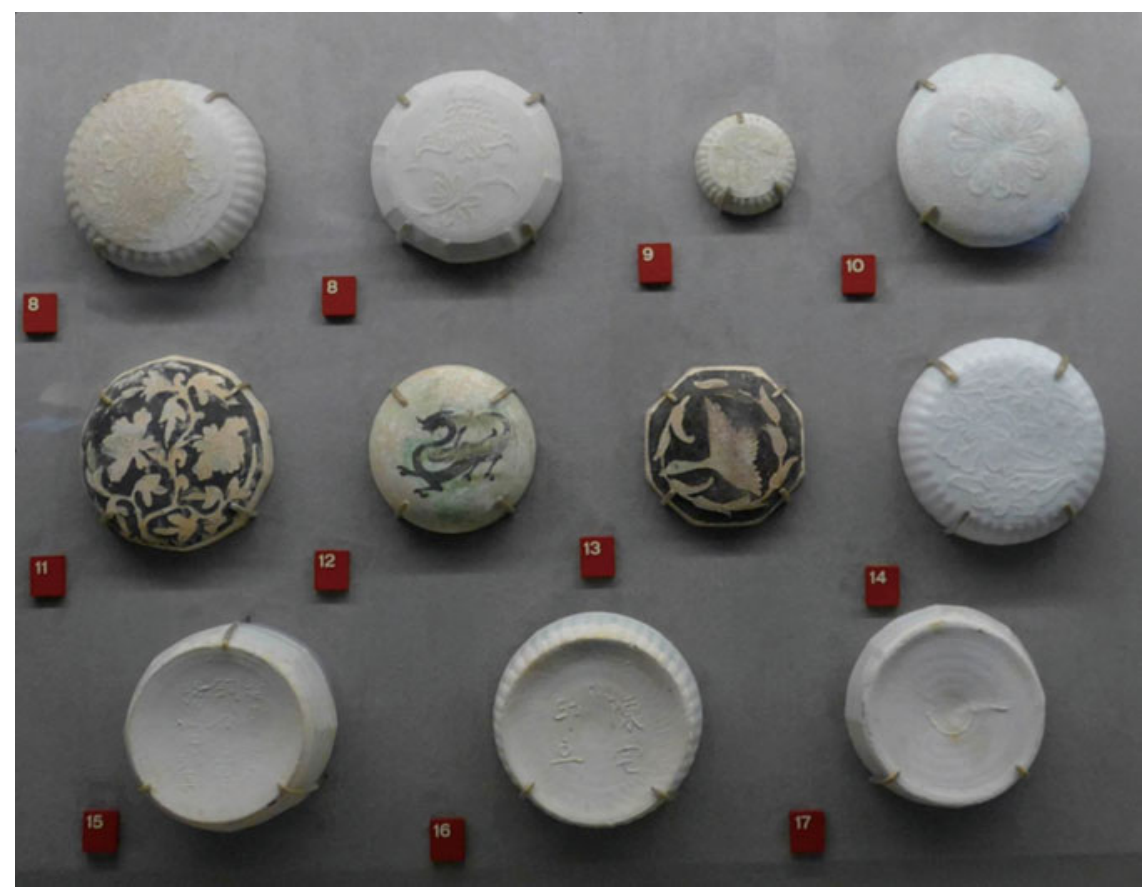

Figure 6. Dehua Qingbai stonewares from the thirteenth-century Java shipwreck, from the collections in the Field Museum, Chicago (photograph by Lin Meicun).

eastern Africa (Figure 7). In the eastern region of the Indian Ocean 'Marco Polo wares' have been mainly found around the Malacca area. For example, the Pengkalan Bujang port site in north-western Malaysia, which dates to the twelfth to thirteenth centuries, has yielded some creamy white and opaque glazed sherds decorated with thin lines in relief. These are also believed to have been produced in the Dehua kilns (Leong, 1973: 216-19). Similar finds have been noted on sites in Kota Cina on the north-eastern coast of Sumatra, which date from the twelfth to early fourteenth centuries (McKinnon, 1984), on Tioman Island, off the east coast of Peninsular Malaysia (Lam, 1985), and on the Temasik sites in Singapore (Miksic, 1985, 2004). 'Marco Polo wares' from the Philippines are only found around Manila, which was probably the only major entrepôt for Chinese products in the thirteenth century (Fox, 1967: 55).

In southern India. the sites at Periyapattinam, Palaya-Kayal, Motupalli, Kunnattur, Pondicherry (see Subbarayalu, 1996; Karashima, 2004), and Pattanam (authors' data), together with the site at Polonnaruwa in Sri Lanka (Prematilleke, 1990; Prickett-Fernando, 1994; Karashima, 2004: 62-63), have produced a large number of sherds of Fujian local kiln-produced or Dehua kiln-produced white/bluish-white stoneware.

In the Gulf, site K103 in the Minab area and other sites along the southern Iranian coast have also yielded these classes of wares and 'Marco Polo wares' have also been recovered from the port of Qalhat in the east of Oman and the port of alNudud, as well as in Kush in the UAE (Morgan, 1991: 70-71; Kennet, 2004: 48- 


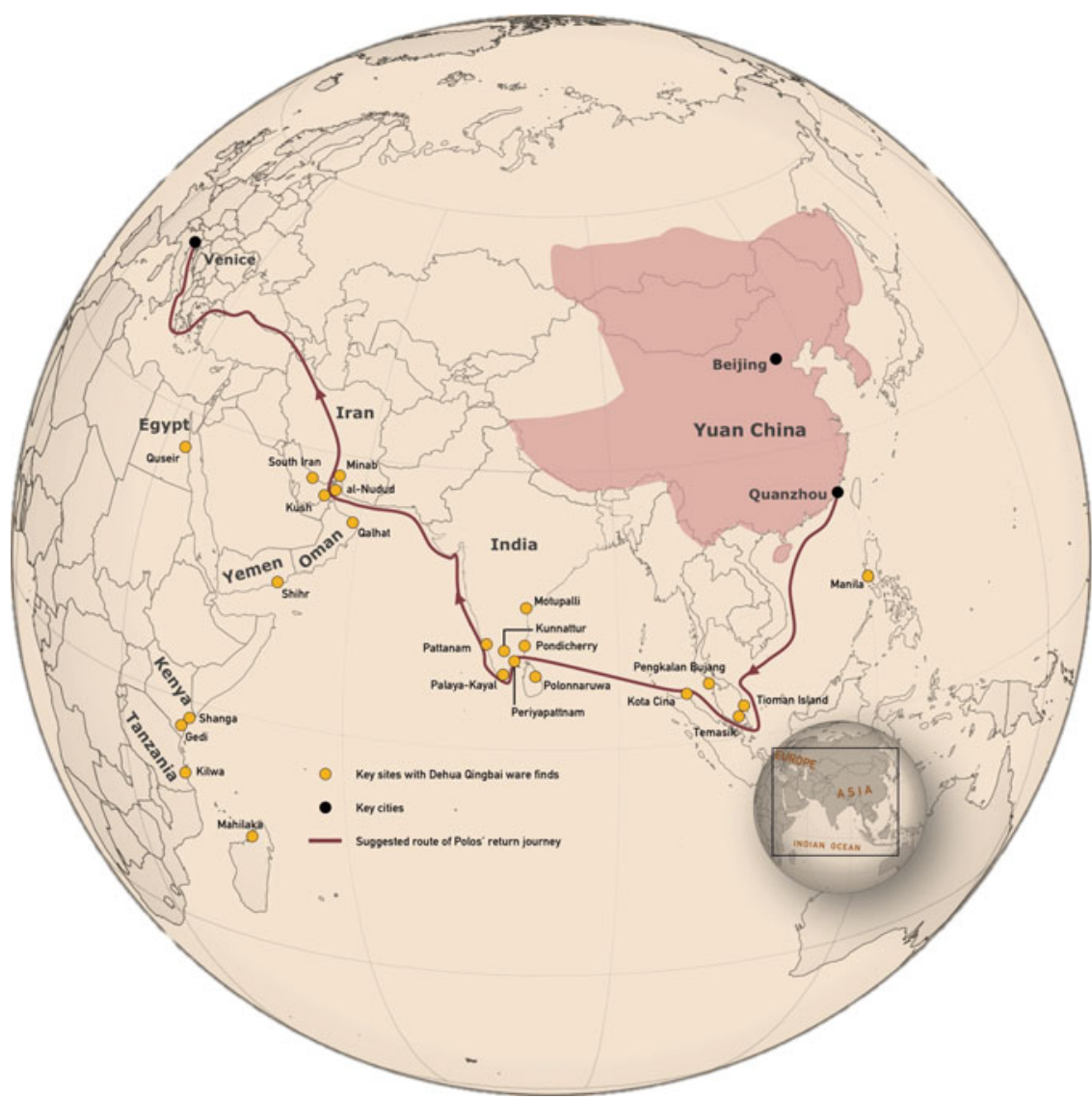

Figure 7. Distribution of Dehua Qingbai wares across the Indian Ocean c. AD 1274-1350 (drawing by Ran Zhang).

49; Priestman, 2005: 294-95; Scalet, 2016: 24). Only a limited number of reports of similar findings have been noted in Yemen and the Red Sea: al-Shihr has yielded socalled fine Dehua sherds, and a few sherds of Dehua Qingbai stoneware have been reported from the site in Quseir in Egypt (Whitcomb, 1983; Hardy-Guilbert \& Rougeulle, 1997; Hardy-Guilbert, 2001, 2005). But it appears that no finds of Dehua Qingbai stonewares have been reported in Fustat, even though it is an important site in northern Egypt (Ma \& Meng, 1987: 4-5; Yuba, 2014). In East Africa, a limited number of 'Marco Polo type' wares have been discovered at the sites of Kilwa (Chittick \& Wheeler, 1974),
Shanga (Horton et al., 1996), Mahilaka in Madagascar (Radimilahy, 1998: 180), and Gedi (Liu et al., 2012).

\section{Discussion: How Strong is The Association of the Dehua Porcelain Wares with Marco Polo?}

Using the evidence described above, the following section aims to further explore the association of Dehua porcelain wares with Marco Polo. It will be seen that the socalled 'Marco Polo jar' and wares are contemporary with Marco Polo and his return journey from China back to the West. 


\section{Dating the 'Marco Polo jar' and the Dehua Qingbai wares}

As mentioned, two possible dates, AD 1307 and 1367 , feature on the clay boxes bearing a cyclical date of 'dingwei (丁未)' unearthed at Qudougong, and these two dates remain open to debate by scholars (Fujiansheng Bowuguan, 1990: 140-42; Lin \& Zhang, 1992: 565; Ho, 2001: 251). The second date was proposed by Ho Chuimei (2001: 251), who suggests that this later date is highly probable. Ho links some white stonewares, also from Qudougong, to wares that were found in association with Yuan blue and white porcelain in burials in the Philippines. Given that no mature blue and white porcelain was made before the early fourteenth century (around the 1330s) (Zhongguo Guisuanyan Xuehui, 1982: 339-42), the production of white stonewares at Qudougong could have lasted into the late fourteenth century, and Ho therefore argues that $\mathrm{AD} 1367$ is the likely date (Ho, 2001: 251).

On the basis of the distribution pattern presented in the previous section, another observation, however, counters Ho's argument, and links it more directly to Dehua Qingbai wares. In the Gulf, the distribution of Dehua Qingbai wares in the Minab area of southern Iran has no association with blue and white porcelain, while many blue and white porcelain sherds but no finds of Dehua Qingbai wares have been discovered on the island of Hormuz (see Morgan, 1991; Priestman, 2005). The Kingdom of Ormus re-settled Hormuz Island from Minab in AD 1325 (Aubin, 1953: 102; Piacentini, 1992: 171-73); it therefore seems that the absence of Dehua wares from Hormuz Island would argue against the later date of the 'dingwei' clay boxes. A similar situation was observed at Fustat, where Dehua Qingbai wares do not occur but many blue and white porcelains do (Ma \& Meng, 1987: 4-5; Yuba, 2014).
Similarly, the cargo found in the Sinan shipwreck off the coast of Korea contained some Dehua Qingbai wares but no mature blue and white porcelains, and this can be dated to AD 1323 (Shen, 2012: 18, 212-13). On this basis, the 'dingwei' clay boxes date to $\mathrm{AD}$ 1307, and the dating of Dehua Qingbai wares of the 'Marco Polo type' should be dated from the late thirteenth to the early fourteenth century. It therefore appears that the date range of Dehua Qingbai wares produced at the Qudougong kiln site can be been narrowed down to match the era of Marco Polo's travel to China.

\section{Longquan celadon pottery versus 'Marco Polo wares'}

When taking a general view of the Chinese ceramic trade during the Yuan dynasty, it should be noted that Longquan celadon pottery, the type which dates to the late thirteenth to fourteenth centuries, has been found in vast quantities across the Indian Ocean (Morgan, 1991; Zhang, 2016: 28185) (Figure 8). It has even been reported that, on rare occasions, the Longquan celadon reached Venice at that time ( $\mathrm{Ye}$, 2000: 12). Celadon pottery was also being produced on a huge scale in the Longquan County of the Lishui City prefecture (丽水 市) in southern China, although the latter was named Chuzhou during the Yuan dynasty. Archaeologically, approximately 445 individual ceramic kiln-workshops have been reported in Longquan and these can be dated to no later than the early fourteenth century (Qin \& Liu, 2012: 10).

The production of celadon ceramic in Longquan County and its consumption across the Indian Ocean was on a much larger scale than that of Dehua Qingbai wares, yet there is not a single word about it in Marco Polo's account. He only very briefly mentions Lishui (Chuzhou); '....at the end of this three-day journey lies the 


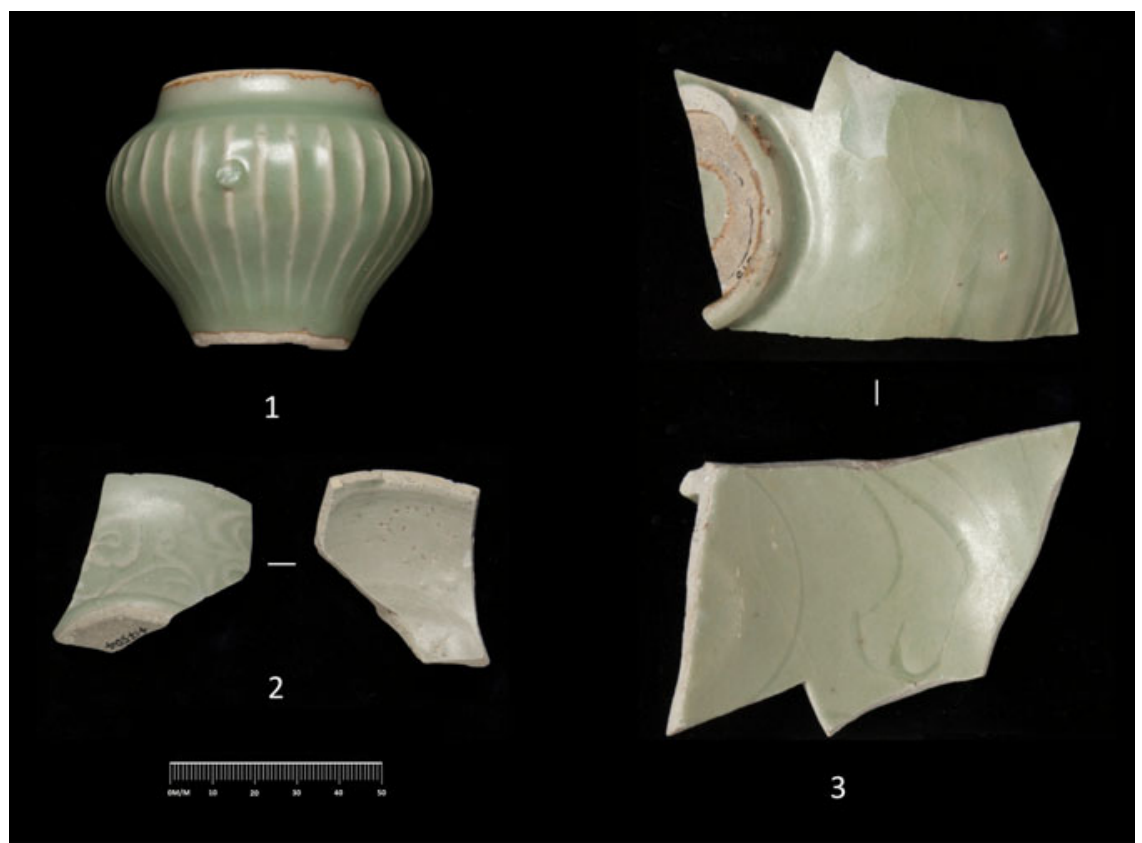

Figure 8. Yuan Chinese Longquan celadon finds from southern Iran, from the Williamson Collections. 1-2) Longquan celadon small jars; 3) Longquan celadon bowl. ( Jeff Veitch. Reproduced by permission of Jeff Veitch.

city of Chuzhou (Cugui/Guiguy), which is very big and beautiful...' (Cliff, 2015: 215). Thus it appears that Marco Polo did not notice that there was a large ceramic industry based around Chuzhou, namely within Longquan County. This could be merely due to the fact that he was not focused on ceramic industries. Or it may be that, because the period of great prosperity of the celadon industry in Longquan County was during the middle to late period of the Yuan Dynasty (Qin \& Liu, 2012: 10), the industry grew after the time of Marco Polo's visit, and may not have been sufficiently developed to attract his attention.

\section{Marco Polo's return route from China to Europe}

It is reasonable to suggest that Marco Polo's return journey included three important stops: i.e. Malacca, Mabar, and Hormuz. Along with the maritime voyage from China to the West, the first stop, Malacca, cannot be omitted for geographical reasons. As for southern India and the Persian Gulf, they were very well recorded by Marco Polo.

Marco Polo claims that his return voyage from China was with an embassy that was taking a bride from the Mongol Royal House to marry her cousin, the Ilkhan of Persia, and this royal marriage has been recorded in both Chinese and Persian sources (Cleaves, 1976). However, there is no direct historical evidence to demonstrate that Marco Polo left China and travelled with these ambassadors, as there is no note of the name of Marco Polo. But Marco Polo clearly mentions the names of the ambassadors he travelled with as Oulatai, Apousca, and Coja, and this could indicate that he did return from China with the embassy (De Rachewiltz, 1997: 47-53). These names 
were recorded by Yongle Dadian (永乐大典 Yongle Encyclopaedia) (Yang \& Ho, 1945; Cleaves, 1976). It seems that this not only reports that Marco Polo left China sometime in late AD 1290 or the very beginning of $\mathrm{AD} 1291$, but it also gives the voyage's final destination, Mabar (Pandya dynasty) in southern India. After his visit to Mabar, Marco Polo claimed he voyaged to the entrance of the Persian Gulf, where he visited Old Hormuz, the Minab area in southern Iran, in AD 1294/1295. He states that this is a regional capital but without describing the fortifications, which were attacked by the son of the ruler of Kish in the 1310s. Ibn Battuta provides descriptions, dating from $\mathrm{AD} 1329$ and 1347, of two places called Hormuz: one on the mainland and another on an island, Hormuz Island (Morgan, 1991: 71, 78). Marco Polo's claims that during his visit to the southern part of the Persian Gulf he saw 'many heavily laden ships arrive [at Qalhat] from India. They find a ready market for their wares, because from here the spices and other goods are carried to many cities and towns in the interior...' (Cliff, 2015: 300).
Marco Polo's return sea voyage to Europe was probably along one of the regular trade routes from China to the West across the Indian Ocean. This is because, historically, knowledge of Mabar was well recorded in Chinese Yuan history, and diplomatic relations were established between Yuan China and Mabar in AD 1281 (Song, 1984: the Countries of Mabar, 4669-70). The Mabar's tribute trade and its commodities have been listed in detail in a book entitled Jie Xing Yu (解醒语) (Ma, 2005: 21). Moreover, archaeological evidence shows that the Chinese ceramic trade was first introduced to southern India on a large scale (Zhang, 2016: 281-85). In addition, some jewellery and gemstones from southern India have been discovered in China, including some Mongolian-style hat ornaments which were found in the Ming (AD 1368-1644) mausoleum of the King of Liang Zhuang in Hubei province (Liang, 2003). These finds are identical to those shown in the Yuan Mongolian Khan's portrait (Figure 9), and can be considered part of the war trophies of the

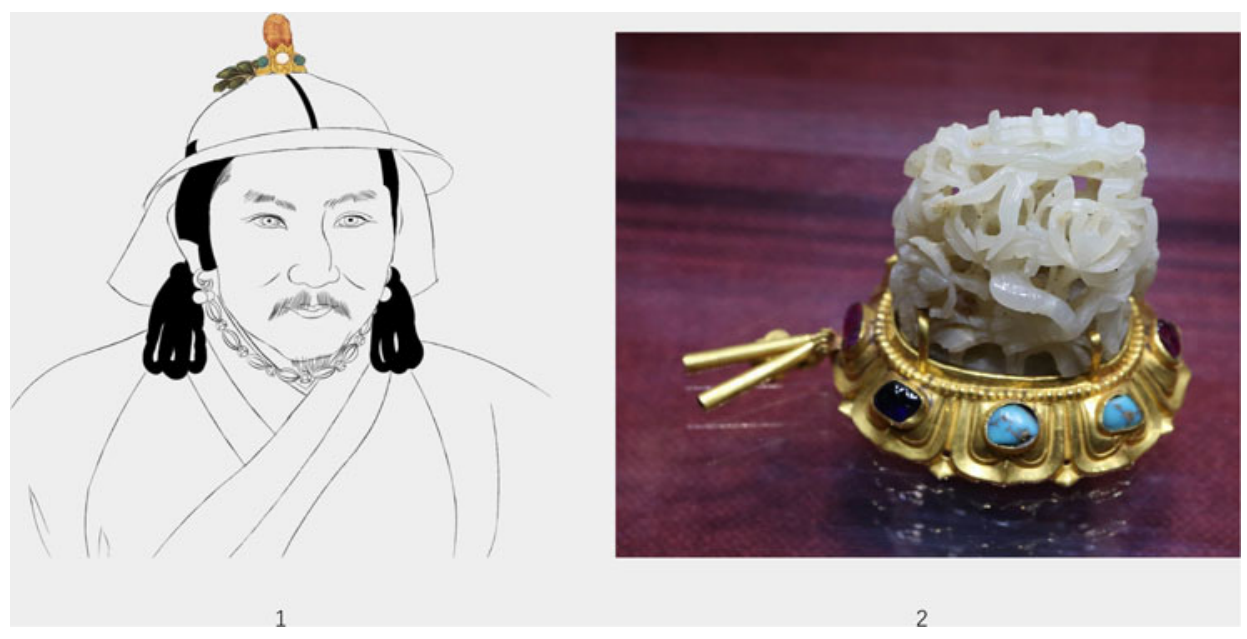

Figure 9. Re-drawing of a portrait of the Mongolian Khan, Emperor Wen-zong, with a hat ornament (1), and Mongolian-style hat ornaments discovered in the mausoleum of King Liang Zhuang (2) (re-drawn by Ran Zhang, after Shi $\mathcal{E}^{2}$ Ge, 2002: 28; photography by Jian Liang). Photograph () Jian Liang. Reproduced by permission of Jian Liang. 
Chinese Ming armies when they re-took the throne from the Yuan Mongolian empire. These items of jewellery and gemstones were given to members of the Ming royal family. Finally, an examination of the distribution map of 'Marco Polo wares' shows that these three locations (Malacca, southern India, and the Persian Gulf) have separately yielded a large number of Dehua Qingbai wares, thereby signifying that Chinese ceramic productions were traded in the Indian Ocean along this regular maritime route.

\section{Conclusions}

The association of the Qingbai porcelain jar housed in the Treasury of San Marco in Venice with Marco Polo was originally made by Oscar Raphael (Raphael, 1932), but it has been widely accepted by many archaeologists without further analysis. This article presents the archaeological evidence on the production and consumption patterns of the Dehua Qingbai porcelain wares that can be dated to the time of Marco Polo. It emerges that the so-called 'Marco Polo jar' and 'Marco Polo wares' are not only dated to the period when Marco Polo visited China, but also that their provenance matches the city where these wares were manufactured, which Marco Polo visited. The claims about the Dehua ceramic industry made by Marco Polo are reasonable and reliable, although he might not have been particularly interested in Chinese ceramics, because he obviously missed the Longquan celadon industry in Chuzhou which he claims to have passed through. Moreover, the archaeological evidence presented here indicates that Marco Polo travelled back to Venice along the route via which 'Marco Polo wares' were traded. He could have therefore acquired the Chinese Qingbai porcelain jar in Dehua city in southern China, or on his journey home.
Behind Marco Polo, there must have certainly been other merchants from Europe, the Persian Gulf, and India who travelled and traded with China; yet Marco Polo's stories are the only historical account that indicate that European merchants could travel to China by both land and sea routes at this time. The 'Marco Polo jar', namely an item of Dehua Qingbai ware, is also the only archaeological evidence that could be linked to Marco Polo, indicating that the European merchants were trading with China in the early fourteenth century. The archaeological finds of Dehua wares presented in this study demonstrate the economic boom in the Indian Ocean trade between China and the West during the thirteenth to fourteenth centuries.

\section{AcKNowledgements}

I am very grateful to the Williamson Collection Project run by Dr Derek Kennet (Department of Archaeology, Durham University), to Professor Robert Layton (Department of Anthropology, Durham University), and Professor Robin Skeates $(E J A)$ for support and suggestions.

\section{REFERENCES}

Anxixian Wenhuaguan [安溪县文化馆] 1977. Fujian Anxi Guyaozhi Diaocha [福建安溪 古窑址调查 (Investigation of Ancient Kilns at Anxi of Fujian)]. Wenwu [文物], 7: 58-65.

Aubin, J. 1953. Les princes d'Ormuz du XIIIe au XVe siècle. Journal Asiatique, 241: 77-137.

Ayers, J. 1988. Blanc de Chine: Some Reflections. Transactions of the Oriental Ceramic Society, 51: 13-36.

Chen, J. [陈建忠] 1999. Debua Minyao Qinghua [德化民窑青花 (Dehua Blue and White Porcelains)]. Beijing: Wenwu Chubanshe.

Chittick, N. \& Wheeler, M. 1974. Kilwa: An Islamic Trading City on the East African Coast. Nairobi: British Institute in Eastern Africa. 
Cleaves, F.W. 1976. A Chinese Source Bearing on Marco Polo's Departure From China and a Persian Source on his Arrival in Persia. Harvard Journal of Asiatic Studies, 36: 181-203.

Cliff, N. 2015. Marco Polo: The Travels. London: Penguin Classics.

Dehua Guciyao Kaogu Fajue Gongzuodui [德 化古瓷窑考古发掘工作队] 1979. Fujian Dehua Qudougong Yizhi Fajue Baogao [福 建德化屈斗宫窑址发掘简报 (Excavation Report of the Qudougong Kiln Site at Dehua, Fujian)]. Wenwu [文物], 5: 51-61.

Deng, M. 1993. Fujian Changting Nanshan Faxian Songdai Yaozhi [福建长汀南山发 现宋代窑址 (Song Ceramic Kilns at Changting Nanshan of Fujian)]. Nanfang Wenwu [南方文物], 4: 20-24.

De Rachewiltz, I. 1997. Marco Polo Went to China. Zentralasiatische Studien, 27: 34-92.

Dubosc, J.P. 1954. Arte cinese. Venice: Alfieri.

Feng, C. [冯承钧] 2001. Ma Ke Bo Luo Xingji [马可波罗行纪 (The Travels of Marco Polo)]. Shanghai: Century Publishing Group of Shanghai.

Flecker, M. 2003. The Thirteenth-Century Java Sea Wreck: A Chinese Cargo in an Indonesian Ship. The Mariner's Mirror, 89: 388-404.

Fox, R. 1967. The Archaeological Record of Chinese Influences in the Philippines. Philippine Studies: Historical and Ethnographic Viewpoints, 15: 41-62.

Franke, H. 1966. Sino-Western Contacts under the Mongol Empire. Journal of the Royal Asiatic Society, Hong Kong Branch, 6: 49-72.

Fujiansheng Bowuguan [福建省博物馆] 1990. Debua Yao [德化窑 (Debua Kilns)]. Beijing: Wenwu Chubanshe.

Fujiansheng Bowuyuan, Dehuaxian Wenwu Guanli Weiyuanhui \& Dehua Taoci Bowuguan [福建省博物院, 德化县文物 管理委员会 \& 德化陶瓷博物馆] 2006. Dehua Mingdai Jiabeishan Yaozhi Fajue Jianbao [德化明代甲杯山窑址发掘简报 (Archaeological Report of the Excavatioins at the Ming Dehua Jiabeishan Kilns)]. Fujian Wenbo [福建文博], 2: 1-15.

Haeger, J.W. 1978. Marco Polo in China? Problems with Internal Evidence. Bulletin of Sung and Yüan Studies, 14: 22-30.

Hamer, F. \& Hamer, J. 1975. The Potter's Dictionary of Materials and Techniques. Philadelphia: University of Pennsylvania Press.
Hardy-Guilbert, C. 2001. Archaeological Research at al-Shihr, the Islamic Port of Hadramawt, Yemen (1996-1999). Proceedings of the Seminar for Arabian Studies, 31: 69-79.

Hardy-Guilbert, C. 2005. The Harbour of alShihr, Hadramawt, Yemen: Sources and Archaeological Data on Trade. Proceedings of the Seminar for Arabian Studies, 35: 71-85.

Hardy-Guilbert, C. \& Rougeulle, A. 1997. AlShihr and the Southern Coast of the Yemen: Preliminary Notes on the French Archaeological Expedition, 1995. Proceedings of the Seminar for Arabian Studies, 27: 129-40.

Haw, S.G. 2006. Marco Polo's China: A Venetian in the Realm of Khubilai Khan. London: Routledge.

Ho, C. [何翠梅] 2001. The Ceramic Boom in Minnan during Song and Yuan Times. In: A. Schottenhammer, ed. The Emporium of the World: Maritime Quanzhou, 10001400. Leiden: Brill, pp. 237-81.

Horton, M.C., Brown, H.W. \& Mudida, N. 1996. Shanga: The Archaeology of a Muslim Trading Community on the Coast of East Africa. London: British Institute in Eastern Africa.

Hughes-Stanton, P. \& Kerr, R. 1980. Kiln Sites of Ancient China: Recent Finds of Pottery and Porcelain. London: Oriental Ceramic Society.

Jackson, P. 1998. Marco Polo and his 'Travels'. Bulletin of the School of Oriental and African Studies, 61: 82-101.

Jiangxisheng Wenwu Kaogu Yanjiusuo \& Jingdezhen Minyao Bowuguan [江西省文 物考古研究所 \& 景德镇民窑博物馆] 2007. Jingdezhen Hutian Yaozhi [景德镇 湖田窑址 (Hutian Kilns in Jingdezhen)]. Beijing: Wenwu Chubanshe.

Karashima, N. 2004. In Search of Chinese Ceramic Sherds in South India and Sri Lanka. Tokyo: Taisho University Press.

Ke, F. \& Chen, H. [柯凤梅 \& 陈豪] 1995. Fujian Putian Guyaozhi [福建莆田古窑址 (Ancient Kilns Site at Putian of Dehua)]. Kaogu [考古], 7: 606-13.

Kennet, D. 2004. Sasanian and Islamic Pottery from Ras al-Khaimab: Classification, Chronology and Analysis of Trade in the Western Indian Ocean (BAR Interntional Series 1248). Oxford: Archaeopress.

Lam, P.Y. 1985. A Ceramic Legacy of Asia's Maritime Trade. Oxford: Oxford University Press. 
Leong, S.H. 1973. A Study of Ceramic Deposits from Pengkalan Bujang, Kedah (unpublished MA dissertation, University of Malaya, Kuala Lumpur).

Li, H. [李辉柄] 1979. Putian Yaozhi Chutan [莆田窑址初探 (Early Investigation of the Putian Kilns)]. Wenwu [文物], 12: 37-42.

Li, S. [李硕卿] 1960. Quanzhou Dongmenwai Wanyaoxiang Guyaozhi Diaocha Yanjiu Qingkuang [泉州东门外碗窑乡古窑址调 查研究情况 (Ancient Ceramics at the Wanyao Xiang of Dongmen Wai in Quanzhou City)]. Quanzhou Haiwai Jiaotongshi Ziliao Huibian [泉州海外交通 史资料汇编], 6: 243-49.

Liang, Z. [梁柱] 2003. Excavation of Prince Liang Zhuang Wang of the Ming Dynasty at Zhongxiang, Hubei [湖北钟祥明代梁庄 王墓发掘简报]. Wenwu [文物], 5: 4-23.

Lin, D. [林德民] 1999. Quanzhou Dongmenyao Chanpin Jiqi Waixiao [泉州 东门窑产品及其外销 (Productions and Exporting of Ceramics at the Dongmen Kilns of Quanzhou City)]. Haijiaoshi Yanjiu [海交史研究], 2: 53-59.

Lin, Z. \& Zhang, W. [林忠干 \& 张文峑] 1992. Songyuan Dehuayao De Fenqi Duandai [宋元德化窑的分期断代 (Chronological Dating of Song and Yuan Dehua Kilns)]. Kaogu [考古], 6: 559-66.

Liu, Y., Qin, D. \& Kiriama, H. [刘岩, 秦大 树 \& 齐里亚马·赫曼] 2012. The Chinese Porcelains Unearthed at Gedi Ruins in the Coast Province, Kenya [肯尼亚滨海省格 迪古城遗址出土中国瓷器]. Wenwu [文 物], 11: 37-60.

Ma, J. [马娟] 2005. Maba'er Guo Yu Yuanchao Zhi Wanglai Jiqi Xiangguan Wenti [马八儿国与元朝之往来及其相关 问题 (Studies of the Communications of Mabar and Yuan)]. Lanzhou Daxue Xuebao [兰州大学学报], 5: 21-25.

Ma, W. \& Meng, F. [马文宽 \& 孟凡人] 1987. Zhongguo Guci Zai Feizhou De Faxian [中国古瓷在非洲的发现 (Chinese Ancient Ceramics Discovered in Africa)]. Beijing: Zijincheng Chubanshe.

McKinnon, E. 1984. Kota Cina: Its Context and Meaning in the Trade of Southeast Asia in the 12th to 14th Centuries (unpublished $\mathrm{PhD}$ dissertation, Cornell University, Ithaca (NY)).

Miksic, J.N. 1985. Archaeological Research on the Forbidden Hill of Singapore: Excavations at Fort Canning. Singapore: National Museum.
Miksic, J.N. 2004. 14th Century Singapore: A Port of Trade. In: J.N. Miksic \& C.A. Low Mei Gek, eds. Early Singapore 1300s-1819: Evidence in Maps, Texts and Artefacts. Singapore: Singapore History Museum, pp. 41-54.

Morgan, D.O. 1996. Marco Polo in China Or Not. Journal of the Royal Asiatic Society, 6: 221-25.

Morgan, P. 1991. New Thoughts on Old Hormuz: Chinese Ceramics in the Hormuz Region in the Thirteenth and Fourteenth Centuries. Iran, 29: 67-83.

Moule, A.C. \& Pelliot, P. 1938. Marco Polo: The Description of the World. London: Routledge.

Olschki, L. 1960. Marco Polo's Asia: An Introduction to his 'Description of the World' Called 'Il Milione'. Berkeley (CA): University of California Press.

Pelliot, P. 1959-1973. Notes on Marco Polo. Paris: Imprimerie Nationale.

Penzer, N.M. 1929. The Most Noble and Famous Travels of Marco Polo. London: Argonaut Press.

Piacentini, V.F. 1992. Merchants, Merchandise and Military Power in the Persian Gulf (Suriyanj / Shabriyaj - Siraf). Memorie dell'Accademia dei Lincei Serie 9, vol. 3. Rome: Accademia Nazionale dei Lincei.

Prematilleke, P.L. 1990. Chinese Ceramics Discovered in Sri Lanka: An Overview. In: S. Bandaranayake, L. Dewaraja, R. Silva \& K. Wimalarante, eds. Sri Lanka and the Silk Road of the Sea. Colombo: Sri Lanka National Commisssion for UNESCO and the Central Cultural Fund, pp. 233-44.

Prickett-Fernando, M. 1994. Middlemen and End Users: The Finds of Yue and Longquan Celadons in Sri Lanka. In: C. Ho, ed. New Light on Chinese Yue and Longquan Wares: Archaeological Ceramics Found in Eastern and Southern Asia, AD 800-1400. Hongkong: Hongkong University, pp. 299-321.

Priestman, S. 2005. Settlement and Ceramics in Southern Iran: An Analysis of the Sasanian and Islamic Periods in the Williamson Collection (unpublished MA dissertation, Durham University).

Qin, D. \& Liu, J. [秦大树 \& 刘净贤] 2012. Meiqing Shuibi Meiyan Qingci [梅清水 碧 美艳青瓷 (Studies of Longquan Celadon)]. Wenwen Yuse Zhao Ciou [温温 玉色照瓷瓯]. Beijing: Shoudu Bowuguan Chubanshe, pp. 1-29. 
Radimilahy, M. de C. 1998. Mahilaka: An Archaeological Investigation of an Early Town in Northwestern Madagascar. Uppsala: Department of Archaeology and Ancient History.

Raphael, O. 1932. Chinese Porcelain Jar in the Treasury of San Marco, Venice. Transactions of the Oriental Ceramic Society, 10: 13-15.

Scalet, S. 2016. News from the Middle East: Chinese Porcelain Sherds from the Medieval Port of Qalhat, Oman. The Oriental Ceramic Society Nerwsletter, 24 (May): 23-25.

Shen, Q. [沈琼华] 2012. Sailing from the Great Yuan Dynasty: Relics Excavated from the Sinan Shipwreck [大元帆影: 韩国新安 沉船出水文物精华]. Beijing: Wenwu Chubanshe Press.

Shi, S. \& Ge, W. [石守谦 \& 葛婉章] 2002. Age of the Great Khan: Pluralism in Chinese Art and Culture under the Mongols [大汉的 世纪: 蒙元时代的多元文化与艺术].

Taipei: National Palace Museum.

Song, L. [宋濂] 1984. Yuanshi, Yingyin Wenyuange Siku Quanshu [元史·影印文波 阁四库全书 (History of Yuan)]. Taiwan: Taiwan Shangwu Yinshuguan Gongsi.

Subbarayalu, Y. 1996. Chinese Ceramics of Tamilnadu and Kerala Coasts. In: Himanshu Prabha Ray \& Jean-Francois Salles, eds. Tradition and Archaeology: Early Maritime Contacts in the Indian Ocean. India: Manohar Publishers and Distributors, pp. 109-14.

Vogel, H.U. 2012. Marco Polo was in China: New Evidence from Currencies, Salts and Revenues. Leiden: Brill.

Wang, G. [王光尧] 2004. Zhongguo Gudai Guanyao Zhidu [中国古代官窑制度 (Studies of Ancient Chinese Imperial Ceramic Forms and System)]. Beijing: Zijincheng Chubanshe.

Whitcomb, D.S. 1983. Quseir Al-Qadim: A Port on the Egyptian Coast of the Red Sea. Proceedings of the Seminar for Arabian Studies, 13: 103-05.

Whitehouse, D. 1972. Chinese Porcelain in Medieval Europe. Medieval Archaeology, 16: 63-78.

Wood, F. 1996. Did Marco Polo Go to China? Asian Affairs, 27: 296-304.

Wright, T. 1854. The Travels of Marco Polo, the Venetian. London: Henry G. Bohn.

Xiong, L. [熊廖] 2006. Zhongguo Taoci Guji Jicheng [中国陶瓷古籍集成 (Collection of Ancient Chinese Ceramic Accounts)]. Shanghai Wenhua Chubanshe.
Yang, C. \& Ho, Y. 1945. Marco Polo Quits China. Harvard Journal of Asiatic Studies, 9: 51.

Ye, W. [叶文程] 2005. Putian Yao [莆田窑 (Putian Kilns)]. Fujian: Fujian Meishu Chubanshe.

Ye, Z. [叶喆民] 2000. Yidali Suocang Zhongguo Gutaoci Kaocha Jilue [意大利所 藏中国古陶瓷考察记略 (Chinese Ceramic Collections Housed in Museums in Italy)]. Journal of the Palace Museum [故宫博物院 院刊], 89: 6-14.

Yuba, T. 2014. Chinese Porcelain from Fustat Based on Research from 1988-2001. Transactions of the Oriental Ceramic Society, 76: 1-17.

Yule, H. \& Cordier, H. 1903. The Book of Ser Marco Polo the Venetian Concerning the Kingdoms and Marvels of the East. London: John Murray.

Zeng, F. [曾凡] 2001. Fujian Taoci Kaogu Gailun [福建陶瓷考古概论 (Introduction to Fujian Ceramic Archaeology)]. Fujian: Fujian Ditu Chubanshe.

Zhang, R. [张然] 2016. An Exploratory Quantitative Archaeological Analysis and a Classification System of Chinese Ceramics Trade in the Western Indian Ocean, AD c. 800-1500 (unpublished PhD dissertation, University of Durham).

Zhang, Z. [张仲淳] 1989. Mingqing Shiqi De Fujian Anxi Qinghua Ciqi [明清时期的 福建安溪青花瓷器 (Ming and Qing Blue and White Porcelain at Anxi Kilns of Fujian)]. Kaogu [考古], 7: 617-23.

Zhongguo Guisuanyan Xiehui [中国硅酸盐学 会] 1982. Zhongguo Taoci Shi [中国陶瓷 史 (Chinese Ceramic History)]. Beijing: Wenwu Chubanshe.

Zhu，B. [朱伯谦] 1989. Longquan Qingci Jianshi [龙泉青瓷简史 (A Brief History of Longquan Celadon)]. In: Zhejiangsheng Qingongye Ting [浙江省轻工业厅] ed. Longquan Qingci Yanjiu [龙泉青瓷研究 (Longqaun Celadon Research)]. Beijing: Wenwu Chubanshe, pp. 1-37.

\section{BiographicAl Notes}

Lin Meicun is a professor of archaeology at Peking University, Beijing. He is the author of Lectures of the Archaeological Silk Road Studies (2006) and A Mongolian 
Map: A Sixteenth Century Chinese Map of the Silk Road Found in Japan (2011). He is interested in Silk Road archaeology and ancient economic and cultural communications. His research covers a wide geographical area, from China to Eurasia, and a long historical period, from prehistory to the Medieval period.

Address: School of Archaeology and Museology, Peking University, 5 Yiheyuan Road, Haidian District, Beijing 100871, China. [linmc@pku.edu.cn]

Ran Zhang is an honorary research associate at the Department of Archaeology, Durham
University. In 2016, he completed his $\mathrm{PhD}$ thesis on 'An Exploratory Quantitative Archaeological Analysis and a Classification System of Chinese Ceramics Trade in the Western Indian Ocean: AD c. 800-1500'. His research is now concerned with how ancient Chinese trade affected the maritime economy in the Indian Ocean and Europe from the eighth to the nineteenth centuries. He also has expertise in the identification and dating of Chinese ceramics.

Address: Department of Archaeology, Durham University, South Road, Durham DH1 3LE, UK. [email: ran.zhang@ durham.ac.uk]

\section{Un pot en porcelaine chinoise associé à Marco Polo : perspective archéologique}

Le premier à avoir prétendu faire le voyage en Chine et en revenir, Marco Polo est un voyageur célèbre dont les descriptions nous éclairant sur la société multiculturelle de l'Eurasie du XIIIe et XIVe siècle. Mais son fameux récit "Le devisement du monde " contient maints mystères qui ont suscité des débats parmi les historiens ; quant à une démarche archéologique, elle a été encore moins fructueuse car le matériel qui pourrait être associé à Marco Polo est extrêmement rare. Une nouvelle étude de la céramique chinoise provenant d'une vaste zone allant de la Chine méridionale à l'Océan Indien apporte quelque soutien de la part de l'archéologie : le pot de porcelaine dans la collection du Trésor de la Basilique Saint Marc à Venise date en effet de l'époque de Marco Polo et on peut sans doute l'associer à son voyage en Chine. Translation by Madeleine Hummler

Mots-clés: Marco Polo, pot de porcelaine Qingbai, céramique chinoise, commerce dans l'Océan Indien

\section{Ein mit Marco Polo verbundenes Porzellangefäß aus archäologischer Sicht besprochen}

Als erster Europäer, der angeblich nach China und zurück gereist ist, hat der berübmte Abenteurer Marco Polo die multikulturelle Gesellschaft des 13. und 14. Jahrhunderts in Eurasien beschrieben. Jedoch enthält sein bekannter Bericht, Das Wunder der Welt, manche ungelöste Rätsel, die von Historiker immer wieder diskutiert werden. Eine archäologische Auswertung ist noch weniger überzeugend, da es sehr selten materielle Nachweise, die mit Marco Polo verknüpft werden können, gibt. Eine Neubewertung der chinesischen Keramik aus einem weiten Gebiet, das sich von China bis in den Indischen Ozean erstreckt, liefert einige neue Hinweise. Es ergibt sich, dass ein chinesisches Porzellangefäß im Schatz von San Marco in Venedig tatsächlich aus der Zeit von Marco Polo stammt und es kann wabrscheinlich mit seiner chinesischen Reise in Verbindung gebracht werden. Translation by Madeleine Hummler

Stichworte: Marco Polo, Porzellangefäß, chinesische Keramik, Handel im Indischen Ozean 